\title{
THE UNDAGI LEXICON IN THE MANUFACTURE OF RESIDENTIAL HOUSES BASED ON ASTA KOSALA KOSALI CONCEPT IN DENPASAR
}

\author{
Sani Damayanthi \\ Warmadewa University \\ Muliawansanidama@gmail.com
}

Received: $19-10-2017$

Revised: 26-10-2017

Accepted: 14-11-2017

How to Cite: Damayanthi.S. (2017) The Undagi Lexicon in the Manufacture of Residential Houses Based on Asta Kosala Kosali Concept in Denpasar. RETORIKA: Jurnal Ilmu Bahasa 3(2). 290-296

DOI: $10.22225 / \mathrm{jr} \cdot 3 \cdot 2.341 .290-296$

\begin{abstract}
The title of this research is The 'Undagi' lexicon in the manufacture of residential houses based on asta kosala kosali concept in Denpasar. The aims of this research is to inventory the diversity of vocabulary of undagi's lexicon in making a house based on asta kosala kosali concept with ecological dimension so that the young generation can know and preserve it well. The theory applied for this research is ecolinguistic theory proposed by Bang and Door (1993). This theory are combines biological dimension, ideological and sociological dimension in the languages. This research is descriptive qualitative. Technique of data collecting is done by applying listening method and speaking method. The listening method is done by using interview technique and the speaking method by using face to face method. The result of the research shows that the diversity of vocabulary of undagis's lexicon in making a house based on asta kosala kosali concept are found sixty seven lexicons categorized as nouns and thirteen lexicons categorized as verb. In addition to word class categorization, in this study also obtained the word forms of each lexicon in the form of a single form of the word base and derivative form of the form of compound words. Each lexicon also has a semantic meaning and shows the social praxis dimension of ideological, sociological and biological dimensions.
\end{abstract}

Keywords: Undagi, asta kosala kosali, the social praxis dimension

\section{INTRODUCTION}

Humans and the environment, both the natural environment and the socio-cultural environment are interrelated systems. Humans in their life will not be separated from social influence, culture, and the natural environment. These three aspects build the mindset or idea of every human being towards its existence in its surrounding environment (Tangkas, 2013). The relationship between language and environment sparked the concept of language environment and environment language. The language of the environment is the language that describes the environment. The language environment recording and constructing the reality of the language environment, while the environment language is the environment or the place where the language is alive. The environment language consists of the human element, the natural environment, and the socio-cultural environment, including the language element which is the reality of the environment language (Mbete, 2011). In Ecolinguistics, the language and its speakers community is seen as a living organism by applying in an environment. Language is also regarded as a system that can develop and change according to human development and shift in- cessantly from time to time (Mbete, 2008). In linguistics, these changes can be seen in many ways. One of the simplest things that can indicate a change is the lexical level.

The existence of the building culture inherited by the Hindus of Bali cannot be separated by the synchronization of Kebo Iwa architecture, Mpu Kuturan, Danghyan Nirartha and Bhagawan Wiswakarma. In the hindu belief, teaches that humans harmonize the universe with all its contents between Bhuana Agung (macrocosm) and Bhuana Alit (microcosm). Each building in Bali is always accompanied by ceremonial worship of Bhagavan Wiswakarma. Such ceremonies are conducted starting from the location selection, making the basic building until the building is complete. This aims to ask blessing to Bhagawan Wiswakarma for the building to live and radiate a positive vibration for its householder. According to the Balinese Hindu belief, the building has the soul of bhuana agung (macrocosmic) while the human who keeps the building is part of the bhuana alit (microcosmic). Between human (microcosmic) and occupied buildings must be harmonious, in order to get the balance between the two realms. Therefore, constructing buildings must be in 
accordance with procedures written in literature Asta Kosala-Kosali.

Balinese people in general and people in particular Denpasar have a rule or a clear benchmark in setting up a building, now known as the traditional Balinese architecture. One of the lontar that contains the rules regarding the development of traditional Balinese architecture is Lontar Asta Kosala Kosali. Asta Kosala Kosali in its main section is usually filled with rules that determine the ideal dimensions of the building, measured by the size of the human body by using the unit of Depa (arm), Lengkat (finger), Tapak (feet). This manuscript most widely used by the undagi in the manufacture of traditional Balinese buildings, one residential building. By applying the concept of Asta Kosala Kosali, the use of the size of the homeowner's body in measurement and not using the tape measure, intended that later the house will be an ideal home for the owner. The undagi has the same reference as other Balinese traditional buildings although there are differences in buildings based on the function of the building. Undagi is the name for a traditional Balinese architect (Gelebet, 1986). An undagi not only equip them with knowledge of the design, but also need to learn and understand the art, culture, customs and religion. It must be controlled by an undagi in the process of designing and creating the work of residential buildings aligned and in line with the concept of Asta kosala-Kosali (Gelebet, 1986).

Concepts are created by grouping and grouping certain objects that share the same characteristics. The concepts are described as follows (Umar, 2004)

\section{Lexicon}

A lexicon is a language component that contains information about meaning. Correspondingly, the lexicon is defined as a vocabulary; a language component containing all the information about the meaning of the use of the word in the language; word richness possessed by a language (KBBI, 2008).

\section{Undagi}

According to Gelebet (1984), Undagi is derived from the word "u-nda-gi" u meaning Shiwa, nda means base, gi means body, the main body undagi, and undagi allowed making gegulak. As known gegulak as a meaningful elbow used to measure measuring in terms of building architectural works, so that an undagi is an architect.

\section{Residential home}

The house is a building that cannot be separated from human life because the house is a primary need for humans as a refuge for people from all interference from outside. In addition, if we see from some sense, the house also functions as a residence or residence, where humans live their lives, where people marry and so forth (Frick, 2006).

\section{Asta Kosala Kosali}

Asta Kosala Kosali in its main section is usually filled with rules that determine the ideal dimensions of the building, measured by the size of the human body by using the measuring unit Tapak (feet), Depa (arm), Lengkat (fingers). This is so that the house will become ideal with the owner of the house. Lontar is the most widely used by the people of Bali in the manufacture of traditional Balinese buildings. One of the physical forms of Balinese architecture using the Asta Kosala-Kosali reference is a residential building. In the architecture of the house, the undagi have the same reference as other Balinese traditional buildings although there are differences in buildings based on the function of the building (Dwijendra, 2008).

\section{Theoretical basis}

According to Snelbecker (1974), theory serves as a vehicle for predicting and explaining observed phenomena. In other words, theory is the fundamental foundation of science as a basic argument for explaining or providing rational answers to the problems cultivated (Atmadilaga, 1994). So the theory used to analyze the problem formulation in this research is the theory of ecolinguistics.

\section{Ecolinguistics}

Crystal (2008: 161-162) in Mbete (2013: 17) gives the following ecolinguistic definitions:

Ecolinguistics (n) in linguistics, an emphasis-reflectioning the notion of ecology in biological studies - in which the interaction between language and cultural environment is seen as central: also called the ecology of language, ecological linguistics, and sometimes green linguistics, an ecolinguistic approach highlight the value of linguistic 
deversity in the world, the importance of individual and communitiy lingusitic rights, and the role of language attitudes, language awareness, language variety, and language change in fostering a culture of communicative peace.

Ecolinguistics in linguistic studies is an emphasis on ecological studies within the scope of depth where interactions between language and environment are seen as interconnected or so-called language ecologists, ecological linguistics, also called green linguistics, an ecolinguistic approach that emphasizes the diversity of languages in world, the importance of language independence individually or in groups, and rules in speech acts, language awareness, language variations, and language changes in the effort to create a polite language culture.

Based on the background, the qualitative descriptive analysis in macro study that is ekolinguistic used in this research to obtain the 'Undagi' lexicon in the manufacture of residential houses based on asta kosala kosali concept in Denpasar.

\section{METHODS}

This research uses qualitative descriptive method in the scope of ecolinguistic studies (macro linguistics). This research is located in Denpasar City. The data required is oral data in the form of lexicon. The lexicon is obtained directly, qualitative data is data obtained through interviews orally. The data obtained in the field are categorized nouns, verbs, and numerals and a combination of words that have the function of representation undagi lexicon in home-making activities based on the concept of kosala kosalan kosali. The data Sources in this study, namely: informants, documents, literature or books are categorized as primary data sources and secondary data. In this study the research instruments used in the form of a list of questions. The list used is a list of questions for unstructured interviews, questionnaires for structured interviews, and lists of lexicon. There are two kinds of data collection method used in this research, that is listening method and conversation method. then the data were analyzed by using qualitative descriptive method. Data presented in the form of a written report from the work of data analysis. The data presented include qualitative data. The application of formal and informal methods is used in presenting the results of data analysis in this study.

\section{DISCUSSION}

Vocabluary Diversity of The Undagi Lexicon in The Manufacture of Residential Houses Based on Asta Kosala Kosali Concept in Denpasar

In this chapter, served on the diversity of the treasures of the undagi lexicon in the manufacture of residential houses on the concept of Asta Kosala Kosali in Denpasar. Data obtained from interviews with informants or informants as primary data, literature and data obtained from existing documents as secondary data. Data were analyzed based on the theories in chapter II. The analysis consists of the categorization of the word class of each lexicon, the word form of the lexicon, the semantic meaning and the dimension of social praxis from the undagi lexicon in the manufacture of residential houses on the concept of Asta Kosala Kosali in Denpasar.

\section{Lexicon Diversity of Undagi, Categorization word, Word form}

The first analysis is an analysis of the categorization of word classes as well as the word form of each lexicon. The data in the form of undagi lexicons in making home based on the concept of kosala kosali kosali categorized in several categories of word classes, among others, namely, the category of nouns and verb categories. In addition lexicons are analyzed into word class form, singular and derived forms.

Lexicon Diversity of philosophy underlying the concept in the manufacture of residential houses based on the concept of Asta Kosala Kosali in Denpasar.

This part is presented about the categorization and form of the lexicons of philosophy underlying the concept in the manufacture of residential houses based on the concept of Asta Kosala Kosali in Denpasar.

Table 1.

The categorization and form of the lexicons of philosophy underlying the concept in the manufacture of residential houses based on the concept of Asta Kosala Kosali in Denpasar. 
RETORIKA: Jurnal Ilmu Bahasa , Vol. 3, No.2 April 2017, Page 293

\begin{tabular}{|c|c|c|c|c|c|c|c|}
\hline \multirow{2}{*}{ No } & \multirow{2}{*}{ Lexicon } & \multicolumn{2}{|c|}{ Environment } & \multicolumn{2}{|c|}{ Categorization } & \multicolumn{2}{|c|}{ Form } \\
\hline & & Biotic & Abiotic & Noun & Verbs & Singular & Derivative \\
\hline 1 & Manik Ring Cuсupu & - & + & + & - & - & + \\
\hline 2 & Tri Hita Karana & - & + & + & - & - & + \\
\hline 3 & Tri Angga & - & + & + & - & - & + \\
\hline 4 & Tri Mandala & - & + & + & - & - & + \\
\hline 5 & Sanga Mandala & - & + & + & - & - & + \\
\hline
\end{tabular}

There are five lexicons of philosophy underlying the concept of kosala kosali kosali in the making of houses. Can be seen from the table, a whole lexicon of nouns and fifth lexicon categorized above has the shape of a derivative. The lexicons are described as follows: The lexicons are described as follows:

\section{Manik Ring Cисирu 'Gems in a jug'}

The manic ring сисирu is categorized into the noun category. Morphologically, the lexicon of the manic ring cucupu consists of three lexemes, the 'gem' manik, the 'in' ring, and the $\mathrm{cu}$ сири 'jug' so that it becomes compound. The ecolexical lexicon of the manic ring сисири belong to the abiotic group. the manic ring $\mathrm{Cu}$ сири lexicon that is categorized as noun is usually spoken by the elder or the elder. The speaking partner of this lexicon speaker is equivalent or younger than the speaker. This lexicon is spoken in a situation of giving advice. By using the manic ring сисири object of the uterus in the mother's womb, the speaker gives advice that his younger-born partner can live in harmony with nature.

\section{Tri Hita Karana 'Tri Hita Karana'}

Tri Hita Karana's lexicon belongs to the noun category. Morphologically, the triangular lexicon of karana consists of three leksem tri 'three', hita 'prosperity', karana 'cause' so it belongs to the form of compound word. Ecoleksically belong to abiotik kelempok. Tri Hita Karana consists of three elements namely atma 'spirit', prana 'force', and 'body' angga. All three are categorized into the noun category and are the basic word form. Tri Hita Karana's lexicon of the noun category is usually spoken by the elder or the elder. The speaking partner of this lexicon speaker is equivalent or younger than the speaker. This lexicon is spoken in a situation of giving advice. By using Tri Hita Karana object that is three relationships of harmony with God, fellow human and nature. The speaker gives advice that his younger partner can run the concept of Tri Hita Karana in his life.

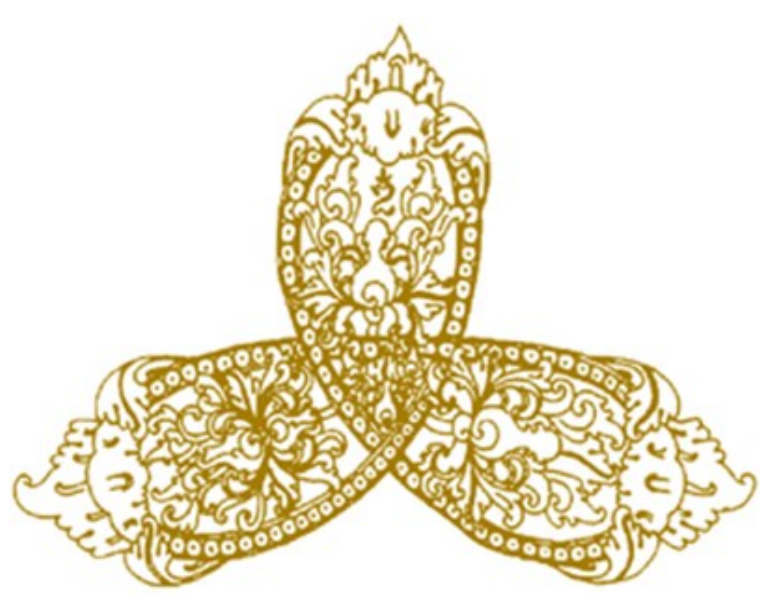

Picture 1. Tri Hita Karana

(resource: http://dwanisme.blogspot.co.id)

Tri hita karana is defined as the three elements of good cause. In essence, the basis of tri hita karana is the harmonization of the relationship between human and god, human with human, and human with environment. Three elements of tri hita karana include atma (spirit), prana (energy), angga (body). These three elements underlie the formation of the cosmos of the macrocosm (bhuana agung) to mikrokosmos (bhuana alit). The universe (macrocosm) and human (microcosm) have the same elements so that the concept of tri hita karana is used in the pattern of housing in Bali. In the dwelling house, the soul is represented as a sanggah pengajan (holy place), man power as the occupant of the house, and the body is the yard of the house. Judging from the aspect of social praxis dimension, the concept of tri hita karana shows the sociological dimension. The sociological dimension can be seen from the meaning of the concept of tri hita karana where human beings have to establish good relationship to god, harmonization of human relationship with fellow human, and harmonization of human relation with environment.

\section{Tri Angga 'Tri angga'}

The tri angga lexicon is morphologically composed of two leksem tri 'three', angga 'body' so that it becomes compound and catego- 
rized in the noun category. In an ecolexical triangle lexicon is included in the abiotic or lifeless category. The tri-lexicon of a categorized noun is usually preached by an elder or an elder. The speaking partner of this lexicon speaker is equivalent or younger than the speaker. This lexicon is said in situations of guidance or direction. By using a tri angga object that is three zones within the holder. The speaker gives guidance or direction so that his or her younger partner or equivalent with the speaker can apply the concept of tri angga so that in making the residential house the settlement zone can run harmoniously.

\section{frama angea l feahre angeges Vista congga}

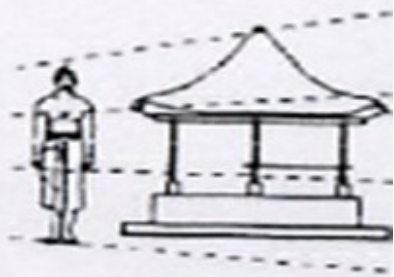
Manusia
Picture 2. Tri Angga

(resource : http://dwanisme.blogspot.co.id)

Tri angga is a derivative of the concept of tri hita karana. Tri Angga divides residential zones in Balinese architecture that follows the concept of kosala kosali kosali. In tri angga, the three zones are divided into the main part of the position or the position of the highest or holy, middle part of the middle lies, and nista is the bottom or dirty. In residential buildings, the main meaning of the angga is the roof of the building, if in the main human body part of the angga is the head. Madya angga that is wall or wall of building, if in human body that is part of body. Nista angga is the base or bottom of a residential building in the form of a rock bed, if in the human body that is the legs. Judging from the social dimension aspects of praxis, the tri-lexicon indicates a biological dimension. This can be seen from the meaning of tri angga which refers to the limbs of man. And the ideological dimension is shown in the concept of tri angga which divides the part of the house into three parts namely the main of the angga, the madya angga, and the nista of the angga.

\section{Tri Mandala 'Tri Mandala'}

Tri mandala's lexicon is morphologically composed of two leksem tri 'three', mandala 'territory' so that it becomes compound and categorized in the noun category. In the ekolexikal lexikon tri mandala included in abiotic or lifeless environment. Tri mandala consists of mandala mandala, mandala mandala, and main mandala. The three lexicons each consist of two leksem so it becomes a compound form and categorized nouns. These three lexicons are abiotic or lifeless environmental groups in the ecolecs. The mandala tri lala that is categorized as noun is usually spoken by the elders or the elder. The speaking partner of this lexicon speaker is equivalent or younger than the speaker. This lexicon is said in situations of guidance or direction. By using the mandala tri object ie three zones within the settlement. The speaker gives guidance or direction so that his or her younger or equivalent counterparts can apply the concept of tri mandala so that in making the settlement house the settlement zone can run harmoniously because the concept of tri mandala is derived from the concept of tri angga.

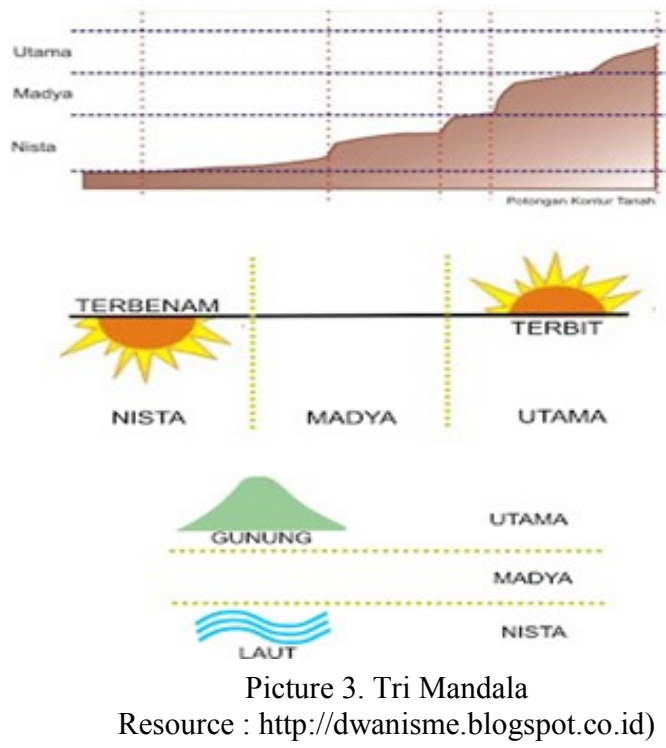

Tri mandala is defined as three regions. In the concept of dwelling house is dug, the three regions or part of the mandala tri is: the main mandala is the symbol of the main house in a house which is realized in the form of a roof and is believed to be a sacred place. Usually within the residence, which belongs to the mandala's main area is pengajan (shrine). Mandya mandala is the central part of a house that manifests sebgai walls, doors, and windows as human habitation. Nista mandala is the foundation of a house or a buffer. At home, located on the front of a house that can be entered by anyone. 
The social praxis dimension contained in the mandala tri lode is the ideological dimension, in which the lexicon of the mandala mandala implies the division of zones within the home.

\section{Sanga Mandala 'Sanga mandala'}

In terms of its categorization, the lexicon of sanga mandala is categorized in the noun category. The lexicon of sanga mandala is a compound form because it consists of two leksem namely sanga 'nine' mandala 'territory'. The lomaikon sanga mandala in ekoleksikal pertained in abiotic or lifeless environment. The sanga mandala that is categorized as noun is usually spoken by the elders or the elder. The speaking partner of this lexicon speaker is equivalent or younger than the speaker. This lexicon is said in situations of guidance or direction. By using the object sanga mandala is the concept of space in the traditional settlement of Bali. The speaker gives guidance or direction so that his or her younger equivalent or equivalent counterparts can apply the concept of sanga mandala so that in the making of residential house the division of residential zone can run harmoniously.

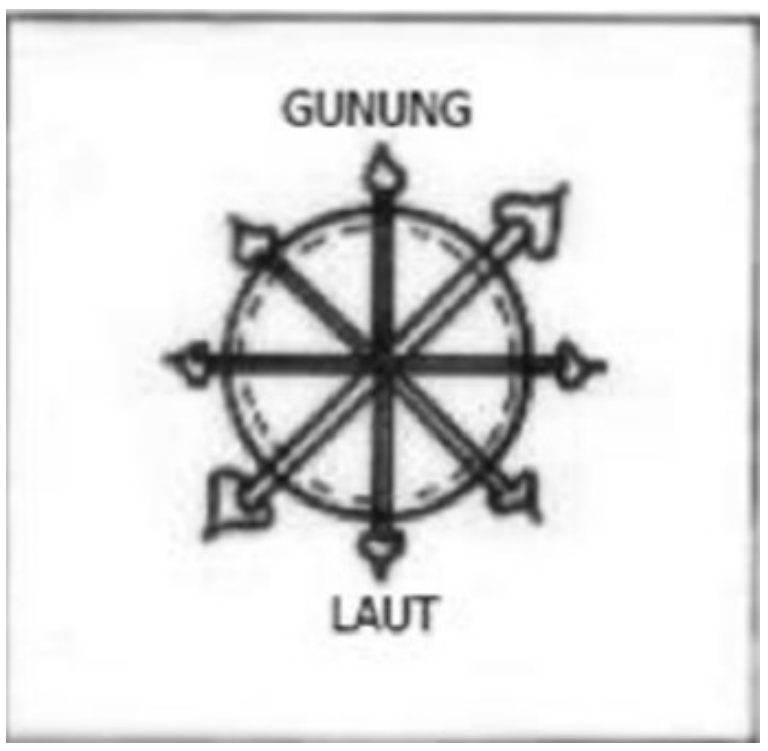

Gambar 4. Sanga Mandala (Sumber: http://

kosmologidanmitologiarsitekturbali.blogspot.co.id/)

Making a home based on the concept of kosala kosali kosali, placement of parts of the house is based on the concept of sanga mandala. The concept of sanga mandala, placing parts of the traditional Balinese house building based on the axis of the mountain with the sea, with the orientation of the mountain lies eastward where the sun rises and the sea lies in the west where the sun sets. With the concept of sanga mandala, the sacred building is placed in the east and the common area is placed in the west. Judging from the social dimensions of social praxis, the lexicon of sanga mandala shows an ideological dimension. This is because the lexicon of sanga mandala gives idrological meaning in Hindu religious teachings where the division of space or zone in the home stay in accordance with the direction of the wind.

The Meaning of Semantic Lexical and Social Praxis Dimensions of The Undagi Lexicon in The Manufacture of Residential Houses on The Concept of Asta Kosala Kosali in Denpasar.

This part is the analysis of the lexical semantic meaning and the social Praxis dimension of each lexicon perundagian based on the concept of asta kosali.

The Meaning of Semantic Lexical and Social Praxis Dimensions of Philosophy Underlying The Concept in The Manufacture of Residential Houses Based on The Concept of Asta Kosala Kosali in Denpasar.

In Hinduism it is taught that humans harmonize the universe with all its contents, the great bhuana (macrocosm) with the bhuana alit (microcosm), this is where the great bhuana (macrocosm) is the artificial environment or the building and the bhuana alit (microcosm) is the man who founded and used such containers (Subandi, 1990). To apply the balance between the great bhuana or the house building with the owner analogous as the bhuana alit, then created the concept of kosala kosala kosali.

Manik Ring Cucupu

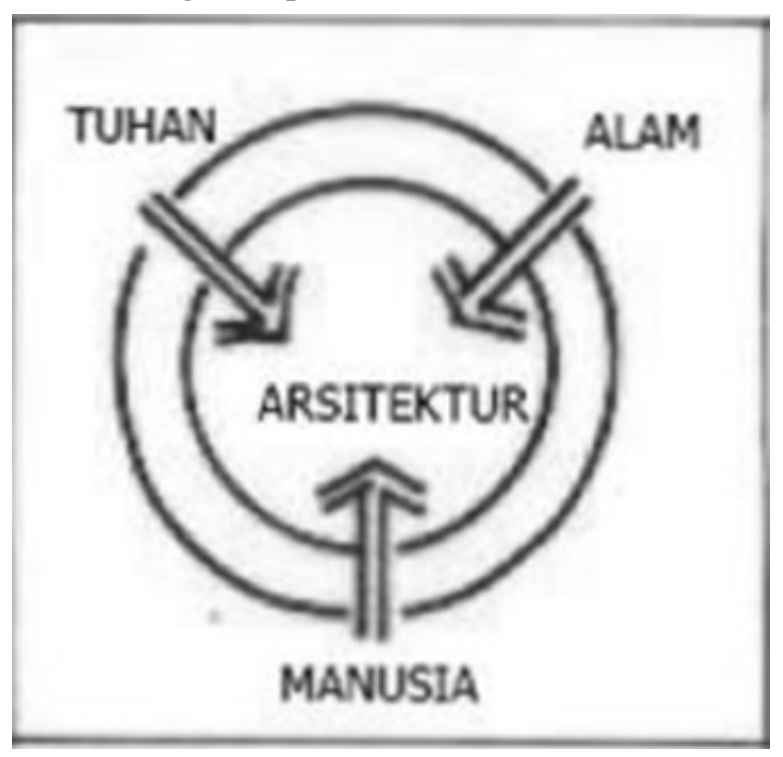


Picture 1. Manik Ring Cucupu

(resource : http://dwanisme.blogspot.co.id)

In Hinduism it is taught that humans harmonize the universe with all its contents, the great bhuana (macrocosm) with the bhuana alit (microcosm), this is where the great bhuana (macrocosm) is the artificial environment or the building and the bhuana alit (microcosm) is the man who founded and used such containers (Subandi, 1990). To apply the balance between the great bhuana or the house building with the owner analogous as the bhuana alit, then created the concept of kosala kosala kosali.

\section{CONCLUSION}

The conclusions obtained from the analysis of the lexicon the undagi lexicon in the manufacture of residential houses on the concept of Asta Kosala Kosali in Denpasar namely:

The diversity of the treasures of the undagi lexicon in the manufacture of residential houses on the concept of Asta Kosala Kosali in Denpasar. form of categorization and form of words. There were sixty seven lexicon split into two categories: fifty-four lexicons of nouns and thirteen lexicons of categorical verbs. In addition to word class categorization, in this study also obtained the word forms of each lexicon in the form of a single form of the word base and derivative form of the form of compound words and affixation form.

Each lexicon - a lexicon in the manufacture of a house based on the concept of kosala kosalan kosali has its own meaning. The lexicon of perundagian in making a home based on the concept of kosala kosali kosali when viewed from the social praxis dimension, shows the dimensions of biological, ideological and sociological dimensions.

\section{ACKNOWLEDGEMENT}

Big gratitude is conveyed to the Head of University of Warmadewa who has become facilitator to the writer in establishing acitvities of studying at Linguistics Study Program for a magisteral degree. Furthermore, gratitude is also addressed to teh Director of Magisteral Program of University of Warmadewa and to all of its line structures who have contributed much of easy access and facilities needed in writing the study.

\section{REFERENCE}

Bang, J.Chr. dan Door, J. 1993. Ecolinguistics: A Framework.

Dwijendra, Acwin Ngakan Ketut. 2008. Arsitektur Rumah Tradisional Bali. Denpasar. Udayana University Press

Gelebet, N.1984. Landasan Filosofis Penentuan Gegulak dan Terapannya dalam Bangunanbangunannya, Denpasar: Pusat Informasi Teknik Bangunan, Kantor Wilayah Departemen PU Propinsi Bali.

Tangkas, Putu Reland Dafincy. 2013. Khazanah Verbal Kepadian Komunitas Tutur Bahasa Kodi, Sumba Barat Daya: Kajian Ekolinguistik. (Tesis). Denpasar:Universitas Udayana. 